\title{
Interaction of rice salinity screening in germination and seedling phase through selection index based on principal components
}

\author{
Muh Farid ${ }^{1}$, Nasaruddin ${ }^{1}$, Muhammad Fuad Anshori ${ }^{1 *}$, Yunus Musa ${ }^{1}$, Hari Iswoyo ${ }^{1}$, \\ and Andi Isti Sakinah ${ }^{1}$
}

'Hasanuddin University, Agronomy Department, 90245, Makassar, Indonesia. "Corresponding author (fuad.pbt15@gmail.com).

Received: 18 January 2021; Accepted: 27 March 2021; doi:10.4067/S0718-58392021000300368

\begin{abstract}
Salinity stress can reduce rice (Oryza sativa L.) productivity and cause crop failure. This problem needs a solution by development of tolerant varieties, and this development closely relates to the effectiveness of its screening. Screening at the phase of germination and seedling are the most common ones. However, the interactions between screenings based on the growth character selection index have not been widely reported, particularly with the principal component analysis (PCA). Therefore, the aim of this study was to determine the interaction between phases of rice salinity screening through a selection index based on PCA. This study consisted of two phases of salinity screening, namely growth phase of germination and seedlings. Both screenings were designed with a nested randomized complete block design, where replicates were nested in a selection environment. The selection environment consisted of two levels, normal $(0 \mathrm{mM}$ $\mathrm{NaCl})$ and saline $(120 \mathrm{mM} \mathrm{NaCl})$. The genotypes consisted of eight varieties and was repeated three times. Observations were based on morphological and physiological characters, especially in seedling phase screening. Results showed that morphological character approach of the seedlings had a large distribution of salinity tolerances. The use of stress tolerance index and PCA were considered effective in the formation of the selection index on salinity screening. As for, the morphology index was formulated as 0.32 shoot height +0.33 root fresh weight +0.33 shoot fresh weight +0.26 root length +0.01 number of tillers, length +0.34 total biomass fresh weight. Therefore, the use of this analytical concept is recommended in screening the tolerance of rice lines to salinity stress.
\end{abstract}

Key words: Principal component, Oryza sativa, rice tolerant, salinity stress, screening interaction, selection index.

\section{INTRODUCTION}

Salinity is one of the main threats to rice (Oryza sativa L.) cultivation, especially for archipelagic countries such as Indonesia (Rumanti et al., 2018). This stress was induced by the rise in sea levels which intrudes on land (Ghosh et al., 2016). This intrusion will increase salt content in rice fields around the coast, so that rice around the area cannot produce optimally (Förster et al., 2011). This was also reported by Rad et al. (2012), an increase in salinity of up to $6 \mathrm{dS} \mathrm{m}^{-1}$ can reduce the potential productivity of rice by $50 \%$ and induce crop failure when salinity level reaches $12 \mathrm{dS} \mathrm{m}^{-1}$. Therefore, in order to maintain rice production in coastal areas, it is necessary to find solutions to overcome these problems. One possible solution is through the development of salt-tolerant varieties.

The development of tolerant varieties should be in line with the development of selection methods. In general, salinity has a negative impact on rice growth through several stresses such as osmotic stress, ion toxicity stress, ion homeostasis stress and oxidative stress (Ismail et al., 2013; Ghosh et al., 2016). The complexity of salinity stress is correlated with the complexity of the tolerance mechanism (Ismail et al., 2013; Acosta-Motos et al., 2017; Reddy et al., 2017), so the tolerance 
screening process requires several approaches and testing at several phases. In general, there are three critical points in screening rice tolerance to salinity stress, namely the germination phase (Pradheeban et al., 2014), early vegetative or seedlings (Ali et al., 2014; Anshori et al., 2020) and productive phase (Safitri et al., 2016; Anshori et al., 2018).

Screening for sprouts and early vegetative phase is a fast and widely used screening method for rice tolerance (Pradheeban et al., 2014; Ali et al., 2014; Mondal and Borromeo, 2016; Diaguna et al., 2017). However, the development of selection characters or selection criteria in screening for salinity tolerance is little known. Screening only focuses on one or two characters and relies on qualitative characters in the form of scoring (Anshori et al., 2020), while salinity tolerance is quantitative (Jahan et al., 2020). In addition, the development of selection indexes on the interaction of several phases and character approaches has also not been widely used. This is the basis of why the development of a selection index for several phases (sprouts and seedlings) and character approaches (morphology and physiology) needs to be expanded.

The selection index is a method of plant breeding for several characters (Acquaah, 2012). This method combines all selection characters with the concept of linear regression. The combination of characters in the regression will produce a certain index value that characterizes a genotype (Islam et al., 2017). This concept is considered effective because the selection is only based on the rank of the genotype index value, hence less strict and more focused to the expected objectives (Acquaah, 2012). However, the crucial part of the selection index formation is the weighting of the values for each selection character (Anshori et al., 2019). One of the methods applicable in index weighting is principal component analysis.

Principal component analysis (PCA) is a multivariate analysis that can condense big data dimensions into simpler ones while maintaining diversity in the original data (Mattjik et al., 2011; Farid et al., 2020). This analysis is widely used in various scientific disciplines, including plant breeding (Acquaah, 2012). The PCA will produce a new variable or principal component (PC) which is a combination of all the initial tested characters (Mattjik et al., 2011). The PC collects the optimal diversity for each character in the form of eigenvector which are the characteristic values of each initial character (Mattjik et al., 2011; Akbar et al., 2018). Therefore, the eigenvector value on a PC can be used as a priority value or initial character weight value on a PC, so that the combination of the eigenvector values of a PC can be used as a basis for forming a selection index (Anshori et al., 2019). This concept development was also reported by Akbar et al. (2018), Anshori et al. (2019), and Alsabah et al. (2019) on double haploid rice lines. Based on this, the development of a selection index for rice salinity tolerance through PCA of several phases and character approaches is interesting and important to do. This paper presents results of a study which aimed to determine the interaction between phases and character approach to rice salinity screening through a selection index based on PCA.

\section{MATERIALS AND METHODS}

A study in the form of experiment was carried out from August to September 2020. This study consisted of two experiments, namely sprout phase salinity screening and seedling phase salinity screening. Screening for salinity in the seedling phase had two-character approaches, namely the morphology and physiology of photosynthesis, while the screening for the germination phase only used morphological characters. The average maximum and minimum temperatures in the greenhouse were 41 and $24.7{ }^{\circ} \mathrm{C}$, while the average maximum and minimum humidity in the greenhouse were $68 \%$ and $43.5 \%$.

\section{Experimental design}

Both experiments were arranged in a nested randomized complete block design, where replicates were nested in a selection environment. The selection environment consisted of normal $(0 \mathrm{mM} \mathrm{NaCl})$ and saline $(120 \mathrm{mM} \mathrm{NaCl})$ media. The rice (Oryza sativa L.) genotypes consisted of Inpari 34 Salin Agritan (salinity tolerant variety), Inpari 29 (immersion tolerant variety), IR 20 (drought sensitive variety), IR 29 (salinity sensitive variety), Salumpikit (drought tolerant variety), Pokkali (salinity tolerant varieties), Ciherang (Indonesian megavariety), Jeliteng (black rice varieties). Each combination was repeated three times, so there were 48 experimental units for each experiment.

\section{Germination phase salinity screening}

The selected seeds were those uniform in size. The seeds were preheated for $72 \mathrm{~h}$ at $43{ }^{\circ} \mathrm{C}$. Before sowing, they were soaked in warm water $\left(48.9^{\circ} \mathrm{C}\right)$ for $15 \mathrm{~min}$ and then in liquid with microbat-enzyme (bacteria-produced plant hormone and biological control) for $24 \mathrm{~h}$. After soaking, seeds were left for $24 \mathrm{~h}$. Seeds that began to germinate were transferred 
into a dish glass. Seeds were sowed by $25 \mathrm{~mL} \mathrm{NaCl}$ solution according to the treatment levels on tissue paper in dish glass. Each experimental unit consisted of 25 seeds. Maintenance of seedlings was carried out for $7 \mathrm{~d}$ and evaluated variables were percentage of germination, sprouts fresh weight, root length, and plumule length.

\section{Seedling phase salinity screening}

This phase was conducted with a hydroponic method according to the modified IRRI Standard Evaluation System (SES) (Anshori et al., 2020). The seeds of each variety have been through the germination screening phase with mineral water solution. Seedlings at the age of $7 \mathrm{~d}$ after sowing (DAS) were transferred to hydroponic culture media. The transplanting was conducted by wrapping the foam at the base of the stem and inserting it into the planting hole in the floating raft installation according to the treatment. Each experimental unit consisted of four seeds. Nutrition was administered with a dose of $5 \mathrm{~mL} \mathrm{~L}^{-1}$ distilled water of $\mathrm{AB}$ mix solution (GOODPLANT, Indonesia) in each stock solution of $\mathrm{A}\left(5 \mathrm{Ca}\left(\mathrm{NO}_{3}\right)_{2} \cdot \mathrm{NH}_{4} \mathrm{NO}_{3} \cdot 10 \mathrm{H}_{2} \mathrm{O}, \mathrm{KNO}_{3}\right.$, FeEDTA, MnEDTA, CuEDTA, ZnEDTA, and $\left.\mathrm{H}_{3} \mathrm{BO}_{3}\right)$ and B $\left(\mathrm{KH}_{2} \mathrm{PO}_{4}\right.$, $\left(\mathrm{NH}_{4}\right)_{2} \mathrm{SO}_{4}, \mathrm{~K}_{2} \mathrm{SO}_{4}$ and $\mathrm{MgSO}_{4} \cdot 7 \mathrm{H}_{2} \mathrm{O}$ ), making the dose of stock solution required for $7 \mathrm{~L}$ was $35 \mathrm{~mL}$ for each type of solution. The transplanted seedlings were adapted to culture media for $7 \mathrm{~d}$. The application of $\mathrm{NaCl}$ treatment was carried out in stages according to the treatment. Half of the $\mathrm{NaCl}$ concentration was given at $14 \mathrm{DAS}$ and the rest was at 16 DAS. It aimed to prevent osmotic shock in seeds (Swapna and Shylaraj, 2017). The $\mathrm{pH}$ of the solution was maintained at 5.05.1 with the use of $\mathrm{NaOH}$ and $\mathrm{HCl}$. In addition, providing water and nutrition as well as checking EC, temperature and humidity were also carried out every day. The observations on this screening were divided into two groups of characters carried out at 35 DAS.

The first observation was on seedling morphology, namely shoot height, root length, number of leaves, number of tillers, root fresh weight, shoot fresh weight and total biomass fresh weight. The second observation was physiological variables consisting of chlorophyll a, chlorophyll b, and total chlorophyll using a chlorophyll content meter (CCM200 plus; ADC Bioscientific Ltd., Hoddesdon, UK) as well as scope, absorption, reflection, and transmission using a leaf spectrometer (CI-710; CID Bio-Science, Camas, Washington, USA). The overall results of the observations were analyzed systematically along with germination screens.

\section{Data analysis}

All character data were analyzed by ANOVA using STAR 2.0.1 software (International Rice Research Institute [IRRI], Los Baños, Laguna, Philippines). Characters significantly affected by interactions were selected and taken for a more in-depth analysis. All of these characters were analyzed using a stress tolerance index (STI) to differentiate the tolerance traits between genotypes. The STI characters that can distinguish between the control varieties of the tolerant ('Pokkali') and the sensitive ('IR 29') were continued with the PCA. The PC was conducted with STAR 2.0.1 software to obtain the basis for the formation of a selection index for each character group (Anshori et al., 2019). All genotypes were analyzed using a selection index for each character group. The results of the index selection between character groups are combined for the genotype grouping process. The combination or interaction between indexes were obtained using R-studio software (RStudio, Boston, Massachusetts, USA) with the scatterplot3d package (Ligges and Mächler, 2003).

\section{Estimation of stress tolerance index}

The stress tolerance index (STI) is calculated using the following formulation (Singh et al., 2015):

$$
\mathrm{STI}=\mathrm{Yp} \times \mathrm{Ys} / \overline{\mathrm{Y}} \mathrm{p}^{2}
$$

where $\mathrm{Yp}$ is the character response under normal environment $\left(4.33 \mathrm{dS} \mathrm{m} \mathrm{m}^{-1}\right)$, Ys is the character response in saline environment $\left(11.49 \mathrm{dS} \mathrm{m}^{-1}\right)$, and $\overline{\mathrm{Y}} \mathrm{p}$ is the average genotype response to characters in normal environment.

\section{RESULTS}

The results of the ANOVA on germination characters, seed morphology and seed physiology on salinity stress are shown in Table 1. Based on germination characters, fresh weight, root length, plumule length, and germination percentage were all influenced $(\mathrm{P}<0.01)$ by varieties $(\mathrm{V})$ and environment $(\mathrm{E})$. The $\mathrm{V} \times \mathrm{E}$ interaction showed an effect $(\mathrm{P}<0.01)$ on fresh weight of sprouts, length of plumules and percentage of germination. Based on this, these three characters with significant interactions were included in the further analysis. 
Table 1. ANOVA of the three character groups in the screening of rice tolerance to salinity stress.

\begin{tabular}{|c|c|c|c|c|}
\hline Variables & Variety (V) & Environment (E) & $\mathrm{G} \times \mathrm{E}$ & $\begin{array}{c}\text { Cumulative } \\
\text { variance }\end{array}$ \\
\hline \multicolumn{5}{|l|}{ Germination } \\
\hline WWS & 0.36 ** & $5.77 * *$ & $0.26 * *$ & 20.89 \\
\hline RL & $1.93^{* *} *$ & $23.70 * *$ & 0.97 & 20.04 \\
\hline LP & $15.83 * *$ & $512.02 * *$ & $8.25 * *$ & 12.29 \\
\hline PG & $294.05^{* *}$ & $3008.33 * *$ & $255.95 * *$ & 8.09 \\
\hline \multicolumn{5}{|c|}{ Seedling morphology } \\
\hline SH & $689.11 * *$ & $2791.82 * *$ & $35.14 *$ & 9.00 \\
\hline NT & $5.98 * *$ & $66.83^{*}$ & $2.95^{* *}$ & 19.15 \\
\hline NL & 96.47 & $526.82 * *$ & 24.14 & 18.14 \\
\hline RL & $67.40 * *$ & $18.68 * *$ & $11.69^{*}$ & 11.73 \\
\hline SFW & $74.09 * *$ & $582.41 * *$ & $31.64 * *$ & 27.95 \\
\hline RFW & $5.77 * *$ & $34.27 * *$ & $1.9 * *$ & 28.67 \\
\hline TBFW & $117.73^{* *}$ & $898.91 * *$ & $47.67 * *$ & 26.92 \\
\hline \multicolumn{5}{|c|}{ Seedling physiology } \\
\hline $\mathrm{Chl} \mathrm{a}$ & $0.45^{* *}$ & $4.82 * *$ & $0.27 *$ & 17.59 \\
\hline $\mathrm{Chl} \mathrm{b}$ & $105.34 * *$ & $1713.27 *$ & 17.70 & 6.42 \\
\hline Chl tot & $0.20 *$ & $2.20 * *$ & 0.12 & 13.65 \\
\hline Scope & $491625.57 *$ & $6068399.41 *$ & $444033.08 *$ & 9.94 \\
\hline Absorption & 0.49 & $1.85^{*}$ & 0.06 & 8.74 \\
\hline Reflection & $1.14 *$ & $14.63 *$ & $1.07 *$ & 10.36 \\
\hline Transmission & $0.91 *$ & $13.55^{*}$ & 0.85 & 9.54 \\
\hline
\end{tabular}

*Significant influence on 5\% error $(\mathrm{P}<0.05)$, **significant influence on $1 \%$ error $(\mathrm{P}<0.01)$.

WWS: Fresh weight of sprouts; RL: root length; LP: length of plumules; PG: percentage of germination; SH: shoot height; NT: number of tillers; NL: number of leaves; SFW: shoot fresh weight; RFW: root fresh weight; TBFW: total biomass fresh weight; Chl a: chlorophyll a; Chl b: chlorophyll b; Chl tot: total chlorophyll.

Table 1 showed the results of the ANOVA on the morphological characters of the seedlings on salinity stress. The varieties had an effect $(\mathrm{P}<0.01)$ on almost all characters, except for the number of leaves. The variance of the selection environment showed an effect $(\mathrm{P}<0.05)$ on all characters. The variance of $\mathrm{V} \times \mathrm{E}$ interactions showed an effect $(\mathrm{P}<0.05)$ on shoot height, number of tillers, root length, shoot fresh weight, root fresh weight, and total biomass fresh weight. The morphological characters of seedlings affected by significant interactions were included in a deeper analysis.

The results of ANOVA of seedlings in salinity stress showed that varieties and environment had an effect $(\mathrm{P}<0.05)$ on all physiological characters of seedlings, except for absorption that was not affected by the varieties. Whereas the variance of interactions $\mathrm{V} \times \mathrm{E}$ only had effect $(\mathrm{P}<0.05)$ on chlorophyll a, scope and reflection. These three characters were included in a deeper analysis of this study.

All characters significantly affected by variety were further analyzed with a stress tolerance index (STI) (Table 2). Based on the STI germination character, 'Pokkali' as a salinity tolerant control had a better STI value than 'IR 29' as a sensitive control for all characters. This forms the basis for PCA.

Based on the PCA on the germination screening character, it shows that PC1 and PC2 are optimal PCs in explaining the diversity of germination screening data. The cumulative proportion in this screening was 0.878 or $87.8 \%$ (Table 3 ).

Table 2. Stress tolerance index (STI) value on eight rice varieties growth characters in the salinity screening of the germination phase.

\begin{tabular}{|c|c|c|c|c|c|c|c|c|c|}
\hline \multirow[b]{2}{*}{ Varieties } & \multicolumn{3}{|c|}{ Normal } & \multicolumn{3}{|c|}{ Saline } & \multicolumn{3}{|c|}{ STI } \\
\hline & WWS & LP & PG & WWS & LP & PG & WWS & LP & PG \\
\hline Ciherang & 1.81 & 12.00 & 100.00 & 0.99 & 5.21 & 93.33 & 0.80 & 0.43 & 0.95 \\
\hline Inpari 29 & 2.02 & 13.79 & 100.00 & 0.59 & 4.39 & 63.33 & 0.54 & 0.41 & 0.64 \\
\hline Inpari 34 & 1.56 & 9.98 & 100.00 & 0.65 & 3.65 & 66.67 & 0.46 & 0.25 & 0.68 \\
\hline IR 20 & 0.69 & 9.38 & 93.33 & 0.77 & 7.79 & 76.67 & 0.24 & 0.50 & 0.73 \\
\hline IR 29 & 1.29 & 13.73 & 100.00 & 0.78 & 5.12 & 83.33 & 0.45 & 0.48 & 0.85 \\
\hline Jeliteng & 1.39 & 11.23 & 100.00 & 0.70 & 5.69 & 93.33 & 0.43 & 0.44 & 0.95 \\
\hline Pokkali & 1.83 & 15.81 & 100.00 & 1.16 & 8.79 & 100.00 & 0.95 & 0.95 & 1.02 \\
\hline Salumpikit & 1.37 & 11.01 & 100.00 & 0.78 & 4.04 & 90.00 & 0.48 & 0.30 & 0.92 \\
\hline Means & 1.50 & 12.12 & 99.17 & 0.80 & 5.59 & 83.33 & 0.54 & 0.47 & 0.84 \\
\hline
\end{tabular}

WWS: Fresh weight of sprouts; LP: length of plumules; PG: percentage of germination. 
Table 3. Analysis of the principal components of the three characteristics of rice salinity screening in the germination phase.

\begin{tabular}{lcrrc}
\hline Variables & PC1 & PC2 & PC3 & Corrected PC1 \\
\hline WWS & -0.595 & 0.142 & 0.791 & 0.426 \\
LP & -0.575 & 0.613 & -0.543 & 0.412 \\
PG & -0.561 & -0.778 & -0.283 & 0.402 \\
\hline PV & 0.716 & 0.162 & 0.122 & \\
CP & 0.716 & 0.878 & 1.000 & \\
\hline
\end{tabular}

PC: Principal component; Corrected PC1: eigenvector PC1 $\times 0.716 \times-1$; WWS: fresh weight of sprouts; LP: length of plumules; PG: percentage of germination; PV: proportion of variance; CP: cumulative proportion.

Meanwhile, PC1 as the main PC collected the diversity of germination initial data of 0.716 or $71.6 \%$. Eigenvector on $\mathrm{PC} 1$ is used as a basis for weighting the germination tolerance index. However, the weights on PC1 are corrected for the diversity of data collected in that PC (corrected PC1).

The results of the STI on morphological characters in the seedling phase salinity are shown in Table 4. The results of the analysis showed that 'Pokkali' had a better STI value than 'IR 29' for all morphological characters of seedling screening. This is also the basis that all the morphological STI characters of seedlings can be included in the PCA.

The results of the PCA of the morphological characteristics of the seedling salinity screening showed that PC1 and PC2 were the optimal PCs in identifying the diversity between seed morphological characters (Table 5). Both PCs had a cumulative proportion of 0.8996 or $89.96 \%$. Meanwhile, PC1 as the main PC had a diversity proportion of 0.7109 . This eigenvector on PC can be used in weighting the morphological tolerance index of seedlings. However, like the germination index, this index also needs to be corrected for the proportion of variance. This is shown in corrected PC1 in Table 5.

Table 4. Stress tolerance index (STI) value on eight rice varieties morphological characters in the seedling phase salinity screening.

\begin{tabular}{lcccccr}
\hline & \multicolumn{7}{c}{ Stress tolerance index } \\
\cline { 2 - 7 } Varieties & SH & RFW & SFW & RL & NT & TBFW \\
\hline Ciherang & 0.54 & 0.40 & 0.19 & 0.82 & 0.64 & 0.24 \\
Inpari 29 & 0.63 & 0.44 & 0.23 & 1.26 & 0.47 & 0.28 \\
Inpari 34 & 0.63 & 0.28 & 0.13 & 1.10 & 0.49 & 0.17 \\
IR20 & 0.44 & 0.09 & 0.05 & 0.63 & 0.43 & 0.06 \\
IR29 & 0.49 & 0.22 & 0.04 & 0.66 & 0.25 & 0.08 \\
Jeliteng & 0.43 & 0.41 & 0.20 & 1.20 & 1.16 & 0.24 \\
Pokkali & 1.62 & 1.02 & 1.13 & 1.22 & 0.52 & 1.12 \\
Salumpikit & 1.05 & 1.27 & 0.61 & 1.88 & 0.49 & 0.77 \\
Means & 0.73 & 0.52 & 0.32 & 1.10 & 0.56 & 0.37 \\
\hline
\end{tabular}

SH: Shoot height; RFW: root fresh weight; SFW: shoot fresh weight; RL: root length; NT: number of tillers; TBFW: total biomass fresh weight.

Table 5. Analysis of the principal components of the six morphological characters of rice in the seedling phase of salinity screening.

\begin{tabular}{llcccccc}
\hline Variables & PC1 & PC2 & PC3 & PC4 & PC5 & PC6 & Corrected PC1 \\
\hline SH & 0.4557 & 0.2414 & 0.2678 & 0.383 & -0.7171 & 0.0383 & 0.32 \\
RFW & 0.4635 & -0.0823 & -0.2886 & -0.7721 & -0.2427 & 0.2002 & 0.33 \\
SFW & 0.464 & 0.0895 & 0.3595 & 0.1115 & 0.5496 & 0.577 & 0.33 \\
RL & 0.3661 & -0.3628 & -0.698 & 0.485 & 0.1088 & -0.0006 & 0.26 \\
NT & 0.0086 & -0.89 & 0.433 & -0.0173 & -0.1417 & -0.0003 & 0.01 \\
TBFW & 0.4776 & 0.0568 & 0.2026 & -0.0959 & 0.3048 & -0.7909 & 0.34 \\
\hline PV & 0.7109 & 0.1887 & 0.0914 & 0.0084 & 0.0005 & 0 & \\
CP & 0.7109 & 0.8996 & 0.9911 & 0.9995 & 1 & 1 & \\
\hline
\end{tabular}

PC: Principal component; Corrected PC1: eigenvector PC1 $\times 0.7109$; SH: shoot height; RFW: root fresh weight; SFW: shoot fresh weight; RL: root length; NT: number of tillers; TBFW: total biomass fresh weight; PV: proportion of variance; $\mathrm{CP}$ : cumulative proportion. 
The results of the STI analysis on the physiological characteristics of the seedling salinity screening showed that the chlorophyll a character of 'Pokkali' had a better STI value than 'IR 29' (Table 6). In contrast to the scope and reflection characters, 'Pokkali' had a lower STI value compared to 'IR 29'. The lower value indicates the tolerance and 'Pokkali' had much lower value than 'IR29' as expected. Therefore, the three characters can still be included in the PCA.

The results of the PCA on the physiological characteristics of seedling screening indicated that PC1 was sufficient to be the optimal PC for use in this analysis (Table 7). This is indicated by the proportion of variance value, 0.82 or $82 \%$. Therefore, the eigenvector on corrected PC can be used as a weighting value base for the physiological tolerance index.

The weighting of the selection index based on PCA analysis in Tables 3,5 and 7 were employed to form the index value for each variety. The index results for each variety of each character group are shown in Table 8 . Based on the three index groups, 'Pokkali' had a greater index value than 'IR 29' in all index groups. The index with the largest difference between the two varieties was the seedling morphology index.

The results of the interaction between germination index, seed morphological index and seed physiological index are shown in Figure 1. Based on this figure, there are four tolerance groups. The first group (red) consisted of 'IR 29', 'Inpari 34' and 'IR 20'. The second group (green) consisted of 'Inpari 29', 'Jeliteng' and 'Ciherang'. The third group (orange) consists of 'Salumpikit' and the last group (blue) consists of 'Pokkali'. 'Pokkali' had diagonal space grouping against 'IR 29'.

Table 6. Stress tolerance index (STI) of eight rice varieties on physiological characters of the salinity screening in the seedling phase.

\begin{tabular}{|c|c|c|c|c|c|c|c|c|c|}
\hline \multirow[b]{2}{*}{ Varieties } & \multicolumn{3}{|c|}{ Normal } & \multicolumn{3}{|c|}{ Saline } & \multicolumn{3}{|c|}{ STI } \\
\hline & Chl a & Scope & Reflection & Chl a & Scope & Reflection & Chl a & Scope & Reflection \\
\hline Ciherang & 144.32 & 3799.93 & 5.83 & 48.21 & 4073.10 & 6.21 & 0.51 & 1.062 & 1.072 \\
\hline Inpari 29 & 126.76 & 3867.35 & 5.88 & 57.73 & 4382.70 & 6.64 & 0.54 & 1.163 & 1.153 \\
\hline Inpari 34 & 114.25 & 3820.21 & 5.82 & 21.13 & 4888.02 & 7.50 & 0.18 & 1.282 & 1.289 \\
\hline IR 20 & 68.84 & 3807.05 & 5.75 & 24.81 & 4632.04 & 7.15 & 0.13 & 1.210 & 1.214 \\
\hline IR 29 & 98.33 & 3855.82 & 5.88 & 5.41 & 5694.06 & 8.69 & 0.04 & 1.507 & 1.510 \\
\hline Jeliteng & 133.76 & 3753.59 & 5.75 & 80.47 & 4174.35 & 6.38 & 0.79 & 1.075 & 1.084 \\
\hline Pokkali & 96.36 & 3847.10 & 5.86 & 26.13 & 3976.19 & 6.07 & 0.19 & 1.050 & 1.053 \\
\hline Salumpikit & 149.71 & 3785.50 & 5.76 & 75.77 & 4405.11 & 6.72 & 0.84 & 1.145 & 1.145 \\
\hline Means & 116.54 & 3817.07 & 5.82 & 42.46 & 4528.20 & 6.92 & 0.40 & 1.19 & 1.19 \\
\hline
\end{tabular}

Chl a: Chlorophyll a.

Table 7. Analysis of the principal components of the three physiological characters of rice in the seedling phase salinity screening.

\begin{tabular}{lccrc}
\hline Variables & PC1 & PC2 & PC3 & Corrected PC1 \\
\hline Chl a & 0.4926 & 0.87 & -0.006 & 0.406 \\
Scope & -0.6148 & 0.35 & 0.705 & -0.506 \\
Reflection & -0.6159 & 0.34 & -0.709 & -0.505 \\
\hline PV & 0.82 & 0.176 & 0.000 & \\
CP & 0.82 & 1.000 & 1.000 & \\
\hline
\end{tabular}

PC: Principal component; Corrected PC1: eigenvector PC1 $\times 0.82$; Chl a: chlorophyll a; PV: proportion of variance; CP: cumulative proportion.

Table 8. Salinity tolerance index of eight rice varieties based on groups of screening characters.

\begin{tabular}{lccc}
\hline Varieties & $\begin{array}{c}\text { Germination } \\
\text { index }\end{array}$ & $\begin{array}{c}\text { Seedling morphology } \\
\text { index }\end{array}$ & $\begin{array}{c}\text { Seedling physiology } \\
\text { index }\end{array}$ \\
\hline Ciherang & 0.90 & 0.67 & -0.87 \\
Inpari29 & 0.66 & 0.85 & -0.95 \\
Inpari34 & 0.57 & 0.69 & -1.23 \\
IR20 & 0.60 & 0.38 & -1.18 \\
IR29 & 0.73 & 0.44 & -1.51 \\
Jeliteng & 0.74 & 0.74 & -0.77 \\
Pokkali & 1.20 & 1.94 & -0.99 \\
Salumpikit & 0.70 & 1.71 & -0.82 \\
\hline
\end{tabular}


Figure 1. Classification of tolerance properties to salinity stress of eight rice varieties.

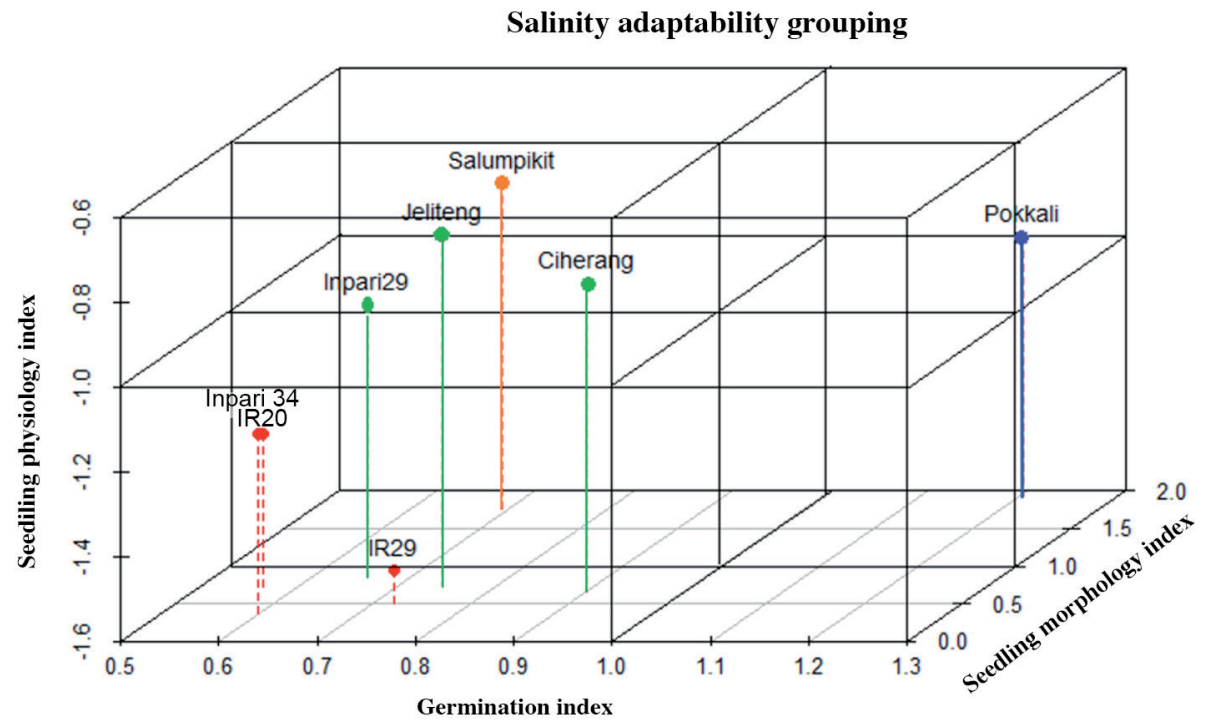

\section{DISCUSSION}

ANOVA in screening tolerance is the initial basis for determining the character of selection in tolerance screening (Anshori et al., 2018; Farid et al., 2020). In addition, this analysis is applicable as a benchmark for the suitability of a method or selection environment (Al-Naggar et al., 2015; Safitri et al., 2016). Based on the results of ANOVA, all characters were significantly affected by the differences in normal and saline growing environment. It is an indication that the applied selection environment was appropriate to see the degree of salinity tolerance of the tested genotypes. Meanwhile, the estimation of the tolerance screening character is determined by the influence of Genotype $\times$ Environment interaction. The significant variance of interactions indicates that there are differences in responses between tested genotypes towards different growing environments (Al-Naggar et al., 2015; Anshori et al., 2019). The difference in response can be a feature of the tolerant and sensitive genotype responses. Therefore, characters that have significant interactions can be indicated as selection character (Ali et al., 2014; Safitri et al., 2016; Fadhli et al., 2020). The application of this concept has been reported by Anshori et al. (2019) on double haploid rice against salinity stress, Fadhli et al. (2020) on maize against drought stress, and Farid et al. (2020) on wheat against temperature stress. Based on this, fresh weight of sprouts, length of plumules, percentage of sprouts, height of shoots, number of tillers, root length, shoot fresh weight, root fresh weight, total biomass fresh weight, chlorophyll a, scope and reflection can be taken as candidates for selection characters in the salinity screening which correspond to the character group.

Stress tolerance index (STI) is an approach in assessing the tolerance properties of a genotype to a certain environmental stress (Singh et al., 2015). This approach is dynamic since the tolerance assessment employs a comparison of the average response of all tested genotypes, especially in normal environments (Anshori et al., 2019; Fadhli et al., 2020; Dehnavi et al., 2020). Therefore, this approach has been widely used by some researchers in selecting genotype tolerance traits under a stress (Kumar et al., 2015; Anshori et al., 2018; Farid et al., 2019). Based on the STI analysis on the germination group, seed morphology, and seed physiology, all characters could distinguish the responses between 'Pokkali' as a tolerant control and 'IR 29' as a sensitive control on salinity screening (Safitri et al., 2016; Anshori et al., 2020). Testing with control varieties is a common method for assessing tolerance, both in determining tolerant genotype (Ahmed et al., 2019; Anshori et al., 2020) and in determining the character of selection (Safitri et al., 2016; 2018; Anshori et al., 2018). Consequently, it is possible to say that the difference in response to STI characters is caused by the tolerance qualities between genotypes towards salinity stress. Therefore, all of these STI characters can be used as selection characters for the screening of salinity tolerance in this research. 
All characters in each group were combined in the form of a selection index through PCA. Based on the results of the PCA, PC1 in all character groups had a high proportion variance (PV) value, i.e., above 70\%. According to Mattjik et al. (2011), Rehman et al. (2019), Akbar et al. (2019) and Anshori et al. (2019), optimizing the representative PC assessment is based on the cumulative proportion which reaches 0.8 . By seeing the comparison of the PC1, PV value against the CP standard, the use of $\mathrm{PC} 1$ as the basis for the selection index was considered sufficient to represent the variance of tolerance properties. All eigenvector values on PC1 also need to be corrected by the PV value by multiplying the eigenvector for each $\mathrm{PC} 1$ to the $\mathrm{PV}$ value. This correction is expected to produce a more representative weighting of the initial data variance (Anshori et al., 2019). However, especially in the germination group, the corrected index value was also multiplied by -1 because the STI characteristic had a positive interpretation. According to Mattjik et al. (2011), negative and positive values for each character on a PC are only the absolute direction or position of the character towards a dimension. Therefore, the corrected PC1 value as a selection index in the germination-screening group could be positive (Table 3 ).

The results of the selection index for each character group indicate that 'Pokkali' has a better index value than 'IR 29'. This indicates that the use of the selection index generated through a combination of STI and weighting of the PCs is considered effective. Meanwhile, the morphological index was considered to be the best index compared to germination and physiological indices. In general, seedling morphology is a complex reflection of the combination of genes related to salinity tolerance, especially if the environment is highly controlled, hence the tolerance difference between tolerant and sensitive genotypes is well observable (Anshori et al., 2020). However, the combination and interaction among all selection indices is still important to do. It aims to assess and classify tolerance response patterns among genotypes to different character approaches and screening phases (Kranto et al., 2016). Therefore, 3D plot grouping can be a solution for mapping the three indices. This was also reported by Farid et al. (2020) through the mapping of character selection results from PCA.

The results of index grouping show varied tolerance patterns with the presence of four tolerance groups. This grouping uses a value of 1 as the constraint for the germination index and seedling morphology index, while the seedling physiology index uses a value of -1 . The value of 1 on the STI indicates that the tolerance response of a genotype has the same response as the average square of the genotype population under normal environment (Singh et al., 2015; Anshori et al., 2019), hence the value of 1 can be used as a tolerance threshold for STI. Based on this concept, the value of 1 can also be applied as a threshold in the germination index and seedling morphology index. In contrast, a value of -1 for the seedling physiology index threshold is due to the negative effect of the variance of these components. The characters of scope and reflection have an inverse interpretation, while STI has a positive interpretation. Therefore, to reconcile the two concepts the value of -1 becomes the optimal value to apply as a threshold in grouping tolerance. Based on the 3D index plot clustering, 'Pokkali' and 'IR 29' show opposite groupings diagonally. It is an indication that this concept is suitable to be applied in assessing the tolerance response to other genotypes.

'Inpari 34' and 'IR 29' are within the same group as 'IR 29', i.e., group 1. 'IR 20 ' is a control variety sensitive to drought stress (Akbar et al., 2018). It is considered quite reasonable when this variety is together with 'IR 29' in a same group. However, 'Inpari 34 Salin Agritan' is a saline-tolerant variety based on its description. The sensitivity results of 'Inpari 34 Salin Agritan' were also reported by Anshori et al. (2019). This is probably due to the static response of this variety's tolerance, hence it has a low index evaluation of dynamic indexes, such as STI. This is also in accordance with the research of Sembiring et al. (2020), who showed that the productivity and components of the 'Inpari 34 Agritan Salin' relatively did not differ too much in normal, moderate and high-saline environments. In addition, the 'Inpari 34 Salin Agritan' tolerance assessment is more focused on the tolerance score and not based on the character of plant growth. Therefore, these varieties are grouped together with 'IR 29', although in terms of their growth potential index they are better than 'IR 29 '.

'Inpari 29', 'Jeliteng' and 'Ciherang' belonged to the same group, i.e., group 2. The three varieties had a good seedling physiology index, but the germination index and seedling morphology index were less than 1 . However, all three varieties had higher seedling morphological index values better than the varieties of group 1 . This indicates that this group has a fairly good salinity tolerance, especially in the seedling phase screening. The potential of 'Inpari 29' as a salinity tolerant variety in the seedling phase was also reported by Safitri et al. (2018) and Anshori et al. (2020). The third group consists of 'Salumpikit' which has good salinity tolerance in the seedling phase screening. However, the tolerant characteristics of the germination phase were almost the same as 'IR 29 '. In general, this variety is a control variety for drought stress 
(Akbar et al., 2018). Salinity stress and drought stress have the same concept of tolerance in osmotic control, especially at the beginning of growth (Ismail et al., 2013; Reddy et al., 2017). In addition, ionic toxic stress at saline condition is accumulative and has moderate stress properties at the beginning of growth (Ismail et al., 2013; Ghosh et al., 2016). Therefore, this variety is considered to have a good tolerance for the salinity screening of the seedling phase.

Based on the grouping of tolerance indexes, all indexes have different response among of them, especially at the germination index. The germination index has a different pattern from the tolerance index in the seedling phase. This is due to differences in enzyme and metabolic mechanisms that correlate with differences in tolerance (Dehnavi et al., 2020). However, when observed on the effectiveness of tolerance grouping, the seedling phase is considered to be more optimal for use in rapid screening of tolerance to salinity stress. This is confirmed by the distribution of high index values among genotypes. Therefore, this method is recommended for rapid screening of rice against salinity stress.

\section{CONCLUSIONS}

Salinity stress has quite varied tolerances, especially between the growth phases of germination and seedlings. The morphological character approach of seedlings has a large distribution of salinity tolerances. The use of stress tolerance index and principal component analysis are effective in the formation of selection indexes in identifying salinity tolerance properties. The use of this analysis in the seedling phase is recommended as a method and tool of selection in the rapid screening of rice lines against salinity stress.

\section{ACKNOWLEDGEMENTS}

We are grateful to the Hasanuddin University for funding this research through the Penelitian Dasar UNHAS Scheme with contract number as 2649/UN4.1/KEP/2020.

\section{REFERENCES}

Acosta-Motos, J.R., Ortuño, M.F., Bernal-Vicente, A., Diaz-Vivancos, P., Sanchez-Blanco, M.J., and Hernandez, J.A. 2017. Review plant responses to salt stress: Adaptive mechanisms. Agronomy 7:18. doi:10.3390/agronomy7010018.

Acquaah, G. 2012. Principles of plant genetics and breeding. $2^{\text {nd }}$ ed. Wiley-Blackwell, Hoboken, New Jersey, USA.

Ahmed, H.G.M.-D., Sajjad, M., Li, M., Azmat, M.A., Rizwan, M., Maqsood, R.H., et al. 2019. Selection criteria for droughttolerant bread wheat genotypes at seedling stage. Sustainability 11(9):2584. doi:10.3390/su11092584.

Akbar, M.R., Purwoko, B.S., Dewi, I.S., and Suwarno, W.B. 2018. Agronomic and drought tolerance evaluation of doubled haploid rice breeding lines derived from anther culture. SABRAO Journal of Breeding and Genetics 50(2):115-128.

Akbar, M.R., Purwoko, B.S., Dewi, I.S., and Suwarno, W.B. 2019. Selection of doubled haploid lines of rainfed lowland rice in preliminary yield trial. Biodiversitas Journal of Biological Diversity 20(10):2796-2801.

Al-Naggar, A.M.M., Sabry, S.R.S., Atta, M.M.M., and Abd El-Aleem, O.M. 2015. Effects of salinity on performance, heritability, selection gain and correlations in wheat (Triticum aestivum L.) doubled haploids. Scientia Agriculturae 10(2):70-83. doi:10.15192/PSCP.SA.2015.10.2.7083.

Ali, M.N., Yeasmin, L., Gantait, S., Goswami, R., and Chakraborty, S. 2014. Screening of rice landraces for salinity tolerance at seedling stage through morphological and molecular markers. Physiology and Molecular Biology of Plants 20(4):411-423.

Alsabah, R., Purwoko, B.S., Dewi, I.S., and Wahyu, Y. 2019. Selection index for selecting promising doubled haploid lines of black rice. SABRAO Journal of Breeding and Genetics 51(4):430-441.

Anshori, M.F., Purwoko, B.S., Dewi, I.S., Ardie, S.W., and Suwarno, W.B. 2019. Selection index based on multivariate analysis for selecting doubled-haploid rice lines in lowland saline prone area. SABRAO Journal of Breeding and Genetics 51(2):161-174.

Anshori, M.F., Purwoko, B.S., Dewi, I.S., Ardie, S.W., Suwarno, W.B., and Safitri, H. 2018. Determination of selection criteria for screening of rice genotypes for salinity tolerance. SABRAO Journal of Breeding and Genetics 50(3):279-294.

Anshori, M.F., Purwoko, B.S., Dewi, I.S., Suwarno, W.B., and Ardie, S.W. 2020. Cluster heatmap for detection of good tolerance trait on doubled-haploid rice lines under hydroponic salinity screening. IOP Conference Series: Earth and Environmental Science 484(1):12001. doi:10.1088/1755-1315/484/1/012001.

Dehnavi, A.R., Zahedi, M., Ludwiczak, A., Perez, S.C., and Piernik, A. 2020. Effect of salinity on seed germination and seedling development of sorghum (Sorghum bicolor (L.) Moench) Genotypes. Agronomy 10:859. doi:10.3390/agronomy 10060859.

Diaguna, R., Suwarno, F.C., and Surahman, M. 2017. Testing method for salinity tolerance at germination stage on rice genotypes. International Journal of Applied Science and Technology 7(3):69-76. 
Fadhli, N., Farid, M., Efendi, R., Azrai, M., and Anshori, M.F. 2020. Multivariate analysis to determine secondary characters in selecting adaptive hybrid corn lines under drought stress. Biodiversitas Journal of Biological Diversity 21(8):3617-3624. doi:10.13057/biodiv/d210826.

Farid, M., Nasaruddin, N., Musa, Y., Anshori, M.F., Ridwan, I., Hendra, J., et al. 2020. Genetic parameters and multivariate analysis to determine secondary traits in selecting wheat mutant adaptive on tropical lowlands. Plant Breeding and Biotechnology 8(4):368-377. doi:10.9787/PBB.2020.8.4.368.

Farid, M., Nasaruddin, R.M., and Ridwan, I. 2019. Tolerance of wheat mutant (Triticum aestivum L.) genotypes in lowland against limited water availability. IOP Conference Series: Earth and Environmental Science 235:012028. doi:10.1088/1755-1315/235/1/012028.

Förster, H., Sterzel, T., Pape, C.A., Moneo-Lain, M., Niemeyer, I., Boer, R., et al. 2011. Sea-level rise in Indonesia: on adaptation priorities in the agriculture sector. Regional Environmental Change 11:893-904. doi:10.1007/s10113-011-0226-9.

Ghosh, B., Md, N.A., and Gantait, S. 2016. Response of rice under salinity stress: a review update. Rice Research: Open Access 4(2):1000167. doi:10.4172/2375-4338.1000167.

Islam, M.R., Kayess, M.O., Hasanuzzaman, M., Rahman, M.W., Uddin, M.J., and Zaman, M.R. 2017. Selection index for genetic improvement of wheat (Triticum aestivum L.) Journal of Chemical, Biological and Physical Sciences 7(1):1-8.

Ismail, A.M., Platten, J.D., and Miro, B. 2013. Physiological bases of tolerance of abiotic stresses in rice and mechanisms of adaptation. ORYZA-An International Journal on Rice 50(2):91-99.

Jahan, N., Zhang, Y., Lv, Y., Song, M., Zhao, C., Hu, H., et al. 2020. QTL analysis for rice salinity tolerance and fine mapping of a candidate locus qSL7 for shoot length under salt stress. Plant Growth Regulation 90(2):307-319. doi:10.1007/s10725-019-00566-3.

Kranto, S., Chankaew, S., Monkham, T., Theerakulpisut, P., and Sanitchon, J. 2016. Evaluation for salt tolerance in rice using multiple screening methods. Journal of Agricultural Science and Technology 18(7):1921-1931.

Kumar, R., Kaul, J., Dubey, R.B., Singode, A., Chikappa, G.K., Manivannan, A., et al. 2015. Assessment of drought tolerance in maize (Zea mays L.) based on different indices. SABRAO Journal of Breeding and Genetics 47(3):291-298.

Ligges, U., and Mächler, M. 2003. Scatterplot3d - an R package for visualizing multivariate data. Journal of Statistical Software $8(11): 1-20$.

Mattjik, A.A., Sumertajaya, I., Wibawa, G.N.A., and Hadi, A.F. 2011. Sidik peubah ganda dengan menggunakan SAS. IPB Press, Bogor, Indonesia.

Mondal, S., and Borromeo, T.H. 2016. Screening of salinity tolerance of rice at early seedling stage. Journal of Bioscience and Agriculture Research 10(01):843-847.

Pradheeban, L., Nissanka, N., and Suriyagoda, L.D.B. 2014. Clustering of rice (Oryza sativa L.) varieties cultivated in Jaffna District of Sri Lanka based on salt tolerance during germination and seedling stages. Tropical Agricultural Research 25(3):358-375. doi:10.4038/tar.v25i3.8045.

Rad, H.E., Aref, F., and Rezaei, M. 2012. Response of rice to different salinity levels during different growth stages. Research Journal of Applied Sciences, Engineering and Technology 4(17):3040-3047.

Reddy, I.N.B.L., Kim, B.-K., Yoon, I.-S., Kim, K.-H., and Kwon, T.-R. 2017. Salt tolerance in rice: focus on mechanisms and approaches. Rice Science 24(3):123-144. doi:10.1016/j.rsci.2016.09.004Get.

Rehman, F., Saeed, A., Yaseen, M., Shakeel, A., Ziaf, K., Munir, H., et al. 2019. Genetic evaluation and characterization using cluster heat map to assess $\mathrm{NaCl}$ tolerance in tomato germplasm at the seedling stage. Chilean Journal of Agricultural Research 79:56-65.

Rumanti, I.A., Hairmansis, A., Nugraha, Y., Susanto, U., Wardana, P., Subandiono, R.E., et al. 2018. Development of tolerant rice varieties for stress-prone ecosystems in the coastal deltas of Indonesia. Field Crops Research 223:75-82. doi:10.1016/j.fcr.2018.04.006.

Safitri, H., Purwoko, B.S., Dewi, I.S., and Ardie, S.W. 2016. Morpho-physiological response of rice genotypes grown under saline conditions. Journal of International Society for Southeast Asian Agricultural Sciences 22(1):52-63.

Safitri, H., Purwoko, B.S., Dewi, I.S., and Ardie, S.W. 2018. Salinity tolerance of several rice genotypes at seedling stage. Indonesian Journal of Agricultural Science 18(2):63-68.

Sembiring, H., Subekti, N.A., Erythrina, E., Nugraha, D., Priatmojo, B., and Stuart, A.M. 2020. Yield gap management under seawater intrusion areas of indonesia to improve rice productivity and resilience to climate change. Agriculture 10(1):1. doi:10.3390/agriculture10010001.

Singh, S., Sengar, R.S., Kulshreshtha, N., Datta, D., Tomar, R.S., Rao, V.P., et al. 2015. Assessment of multiple tolerance indices for salinity stress in bread wheat (Triticum aestivum L.) Journal of Agricultural Science 7(3):49-57.

Swapna, S., and Shylaraj, K.S. 2017. Screening for osmotic stress responses in rice varieties under drought condition. Rice Science 24(5):253-263. doi:10.1016/j.rsci.2017.04.004. 